\title{
Effect of Glass Fibres on Ordinary Portland cement Concrete
}

\author{
Deshmukh S.H. ${ }^{1}$, Bhusari J. ${ }^{2}$, Zende A. M. ${ }^{3}$ \\ 1 \& 2 Singhgad college of Engineering, Pune \\ ${ }^{3}$ Pune Institute of Computer Technology, Pune
}

\begin{abstract}
Concrete is a tension weak building material, which is often crack ridden connected to plastic and hardened states, drying shrinkage, and the like. Moreover, concrete suffers from low tensile strength, limited ductility and little resistance to cracking. In order to improve these properties, and attempt has been made to study the effect of addition of glass fibers in ordinary Portland cement concrete. In the present experimental investigation glass fibers in different percentage 0 to $0.1 \%$ has been studied for the effect on mechanical properties of concrete by carrying compressive strength test, flexural strength test and splitting tensile strength test. The results have shown improvement in mechanical and durability properties with the addition of glass fibers.
\end{abstract}

Key words: Glass fibre, compressive strength, split tensile, flexural strength

\section{Introduction}

The concrete without any fibres will develop the cracks due to plastic shrinkage, drying shrinkage and other reasons of changes in volume of concrete. The development of these micro cracks causes elastic deformation of concrete. Plain concrete is a brittle material and having the values of modulus of rupture and strain capacity is low. In order to meet the required values of flexural strength and enhances the strain capacity of the plain concrete, the fibres are being used in normal concrete. The addition of fibres in the plain concrete will control the cracking due shrinkage and also reduce the bleeding of water. The addition of glass fibres in plain concrete shows higher flexural strength than plain concrete. Environmental and economic considerations played a great role in the increase in use of mineral admixtures. Cement with pozzolana like fly ash reduces the permeability of concrete and dense calcium silicate hydrate $(\mathrm{C}-\mathrm{S}-\mathrm{H})$. A preliminary test program has been carried out to study the mechanical characteristics of glass fibre reinforced concrete with the percentage of glass fiber 0 to 0.1 .

\section{Review of literature}

Reduction of both water absorption and chlorine ion permeability in the specimen showed that natural pozzolana is not only suitable for high performance concrete but also results in better properties than the control concrete. Permeability of concrete allows aggressive chemicals such as chlorides and sulphates to penetrate through concrete causing damage. In fact, chloride diffusion and sulphate attack are the main reasons for concrete deterioration. The ability of concrete to resist chemical attack is characterized by permeability and diffusivity which are considered as "durability indicators" [Talah Aissa et.al. 2011]. Fibre Reinforced Polymers in new and existing structures is increasing at a rapid pace. The environmental parameters to which the specimens were subjected included freeze-thaw cycling of 50, 100, 200, and 300 cycles, UV radiation of 1200, 2400, and 4800 hours, temperature variation of 28,56,112, and 336 cycles, $\mathrm{NaOH}$ solutions with $\mathrm{pH} 10$ and $\mathrm{pH} 12$ concentrations of 7, 14, 28, and 84 days, and moisture for 7, 14, 28, and 84 days [S.M.Homam, et.al., 2004].

\section{Experimental Programme \\ 3.1 Materials Cement}

The ingredients of cement primarily consist of calcareous materials in the form of limestone, chalks and marl and argillaceous materials. The ordinary Portland cement of 53 Grade is used. The specific gravity of cement is 3.15. For ordinary Portland cement, the initial setting time is 55 minutes and the final setting time is 600 minutes.

\author{
Aggregate \\ Fine aggregate is a material such as sand, crushed stones or crushed gravel passing through $4.75 \mathrm{~mm}$ size. Locally available sand \\ is used as fine aggregate in the concrete mix. The specific gravity of fine aggregate is 2.71 . \\ Material which retained on $4.75 \mathrm{~mm}$ size is classified as coarse aggregate. For most works, $20 \mathrm{~mm}$ aggregate is suitable. The \\ locally available $20 \mathrm{~mm}$ size of aggregate is used. The specific gravity of coarse aggregate is 2.94 .

\section{Glass Fibers} \\ The glass fibers used in concrete suppressed the localization of micro cracks in to macro cracks hence tensile strength increase. It \\ improves durability of concrete by increasing the strength of concrete. The Glass Fibers are of Cem-FIL Anti - Crack HD with
}


IOSR Journal of Engineering

June. 2012, Vol. 2(6) pp: 1308-1312

modulus of elasticity $72 \mathrm{GPa}$, Filament diameter 14 microns. Specific Gravity is 2.68 , length $12 \mathrm{~mm}$ and having the aspect ratio of 857.1. The number of fibers per $1 \mathrm{~kg}$ is 212 million.

\subsection{Mix Proportions}

In this study, control mix A was designed as per IS 10262:1982 to achieve a target compressive strength of $20 \mathrm{MPa}$. The glass fibres of $0 \%, 0.03 \%, 0.06 \%$ and $0.1 \%$ by volume fraction of concrete were used.

\subsection{Preparation and Details of Test Specimens}

In the present experimental investigation cubes of $150 \mathrm{~mm} \times 150 \mathrm{~mm} \times 150 \mathrm{~mm}$ of M-20 grade concrete were casted with varying percentage of addition of $0.03 \%, 0.06 \%$ and $0.1 \%$ of glass fibre. After casting, test specimens were demoulded after 24 hours and were kept in the curing tanks until the time of test.

\subsection{Tests on Concrete}

Casting and testing of cubical specimens of size $150 \mathrm{~mm} \times 150 \mathrm{~mm} \times 150 \mathrm{~mm}$ for compressive strength, flexural strength test and splitting tensile strength test test was done as per IS:516-1959 specification compressive strength test was performed on $150 \mathrm{~mm}$ cubes, tested at 28 days, with their specimen in each case and cured in the water tank completely immersed at constant temperature $28^{\circ}-30^{\circ} \mathrm{C}$ until the test age. All the test specimens were demodulate 24 hours after casting.

Table 1 - Compressive strength test result

\begin{tabular}{|c|c|c|c|c|}
\hline Type of concrete & Cube & Crushing load KN & $\begin{array}{c}\text { Compressive } \\
\text { strength } \mathrm{N} / \mathrm{mm}^{2}\end{array}$ & $\begin{array}{l}\text { Average compressive } \\
\text { Strength } \mathrm{N} / \mathrm{mm}^{2}\end{array}$ \\
\hline \multirow{3}{*}{$\begin{array}{l}\text { M-20 with } 0.0 \% \\
\text { glass fiber }\end{array}$} & N1 & 600 & 26.67 & \multirow{3}{*}{23.93} \\
\hline & N2 & 515 & 22.88 & \\
\hline & N3 & 500 & 22.22 & \\
\hline \multirow{3}{*}{$\begin{array}{l}\text { M-20 with } 0.03 \% \\
\text { glass fiber }\end{array}$} & $3 a$ & 540 & 24 & \multirow{3}{*}{26.07} \\
\hline & $3 b$ & 538 & 23.91 & \\
\hline & $3 c$ & 682 & 30.31 & \\
\hline \multirow{3}{*}{$\begin{array}{l}\text { M-20 with } 0.06 \% \\
\text { glass fiber }\end{array}$} & $6 a$ & 545 & 24.22 & \multirow{3}{*}{26.6} \\
\hline & $6 \mathrm{~b}$ & 540 & 24 & \\
\hline & $6 c$ & 711 & 31.6 & \\
\hline \multirow{3}{*}{$\begin{array}{l}\text { M-20 with } 0.1 \% \\
\text { glass fiber }\end{array}$} & $1 \mathrm{a}$ & 430 & 19.11 & \multirow{3}{*}{29.54} \\
\hline & $1 \mathrm{~b}$ & 680 & 30.22 & \\
\hline & $1 \mathrm{c}$ & 884 & 39.29 & \\
\hline
\end{tabular}

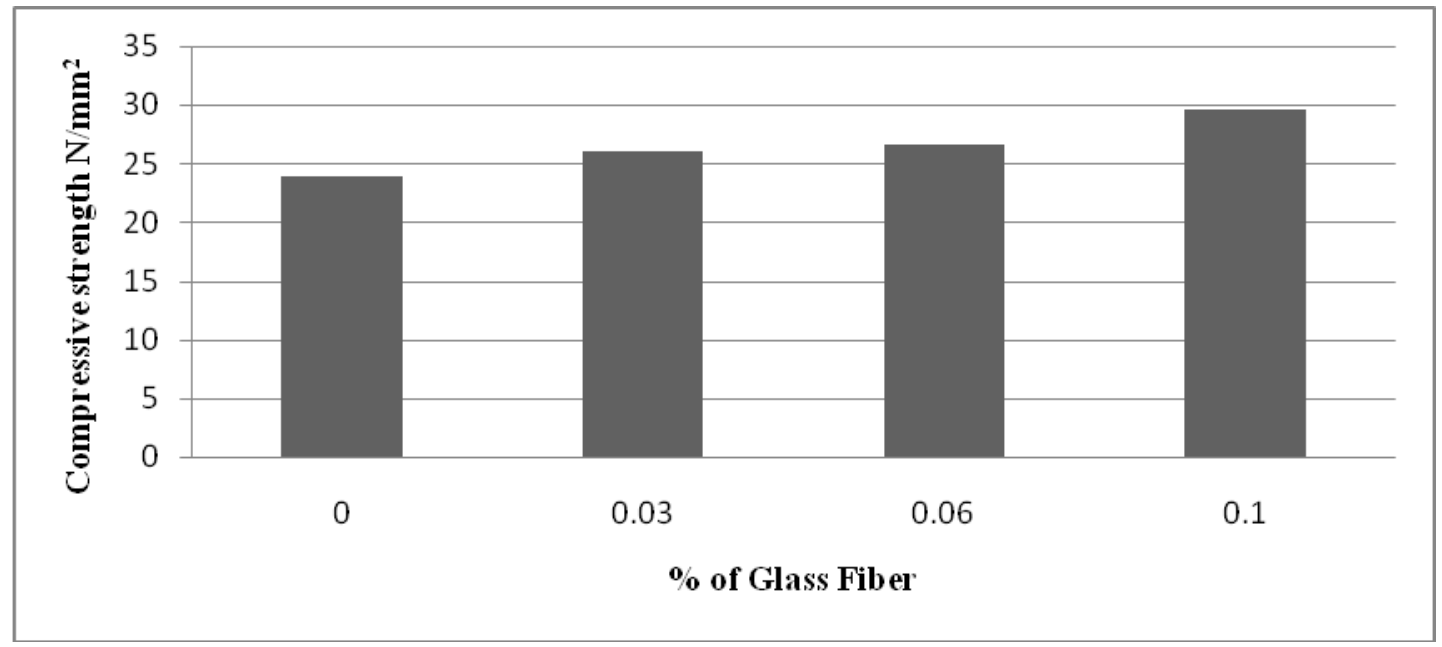

Fig. 1 Compressive strength of $\%$ of Glass Fiber 
IOSR Journal of Engineering

June. 2012, Vol. 2(6) pp: 1308-1312

Table 2 - Flexural strength test result

\begin{tabular}{|c|c|c|c|c|}
\hline Type of concrete & Beam & Crushing load KN & $\begin{array}{l}\text { Flexural strength } \\
\mathrm{N} / \mathrm{mm}^{2}\end{array}$ & $\begin{array}{l}\text { Average Flexura } \\
\text { Strength N/mm }\end{array}$ \\
\hline \multirow{3}{*}{$\begin{array}{l}\text { M-20 with } 0.0 \% \\
\text { glass fiber }\end{array}$} & N1 & 16.2 & 3.312 & \multirow{3}{*}{3.344} \\
\hline & $\mathrm{N} 2$ & 14.31 & 2.86 & \\
\hline & N3 & 19.32 & 3.86 & \\
\hline \multirow{3}{*}{$\begin{array}{l}\text { M-20 with } 0.03 \% \\
\text { glass fiber }\end{array}$} & $3 a$ & 15.3 & 3.06 & \multirow{3}{*}{3.587} \\
\hline & $3 b$ & 18.48 & 3.696 & \\
\hline & $3 c$ & 20.03 & 4.006 & \\
\hline \multirow{3}{*}{$\begin{array}{l}\text { M-20 with } 0.06 \% \\
\text { glass fiber }\end{array}$} & $6 a$ & 16.48 & 3.296 & \multirow{3}{*}{3.654} \\
\hline & $6 \mathrm{~b}$ & 18.50 & 3.7 & \\
\hline & $6 c$ & 19.84 & 3.968 & \\
\hline \multirow{3}{*}{$\begin{array}{l}\text { M-20 with } 0.1 \% \\
\text { glass fiber }\end{array}$} & $1 \mathrm{a}$ & 17.74 & 3.548 & \multirow{3}{*}{3.99} \\
\hline & $1 \mathrm{~b}$ & 20.08 & 4.018 & \\
\hline & $1 \mathrm{c}$ & 22.15 & 4.43 & \\
\hline
\end{tabular}

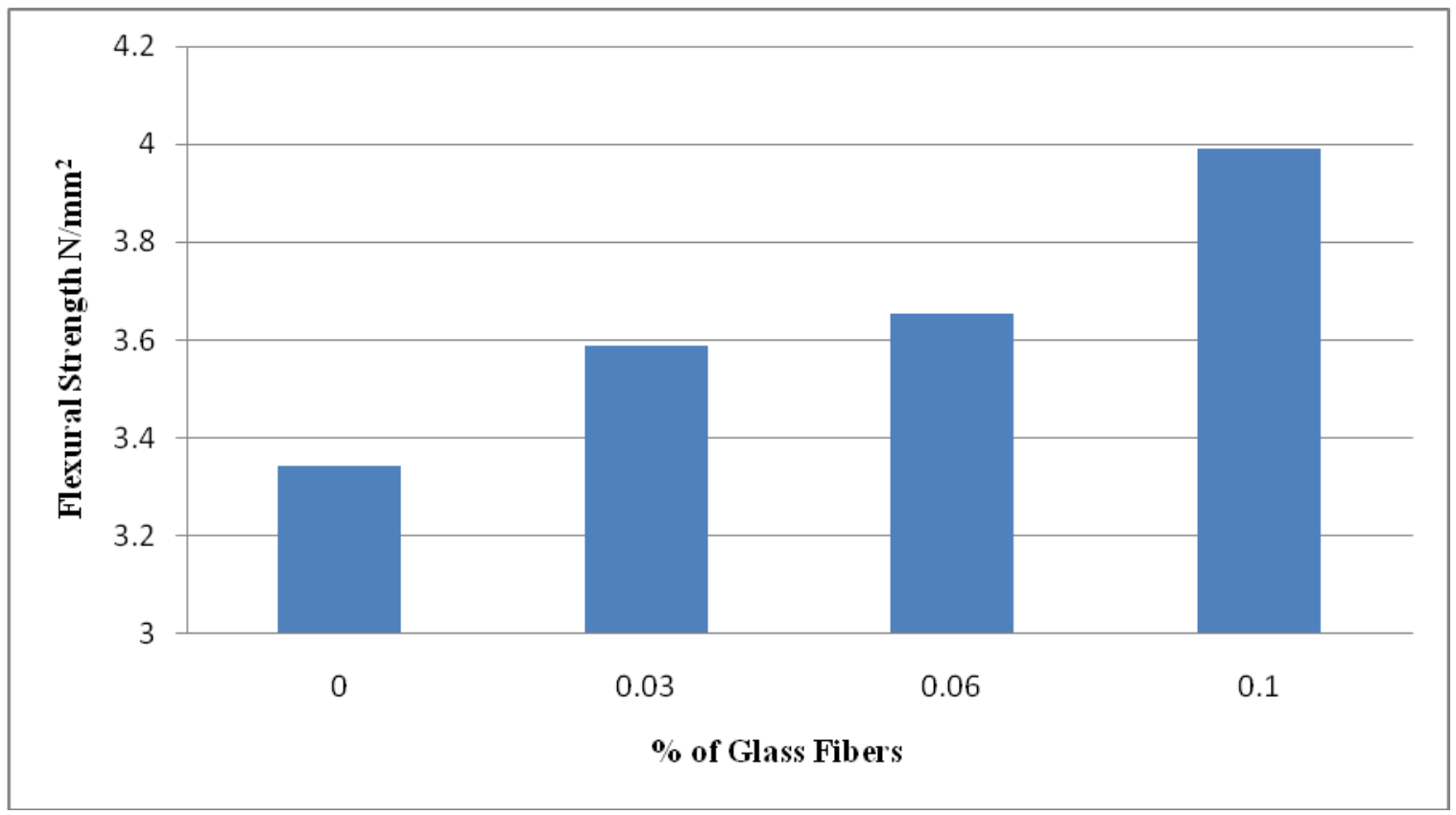

Fig. 2 Flexural strength of $\%$ of Glass Fiber 
IOSR Journal of Engineering

June. 2012, Vol. 2(6) pp: 1308-1312

Table 3 - Splitting Tensile Strength Test Result

\begin{tabular}{|c|c|c|c|c|}
\hline Type of concrete & Cylinder & Crushing load KN & $\begin{array}{l}\text { Splitting Tensile } \\
\text { strength } \mathrm{N} / \mathrm{mm}^{2}\end{array}$ & $\begin{array}{c}\text { Average Splitting } \\
\text { Tensile Strength } \\
\mathrm{N} / \mathrm{mm}^{2}\end{array}$ \\
\hline \multirow{3}{*}{$\begin{array}{l}\text { M-20 with } 0.0 \% \\
\text { glass fiber }\end{array}$} & N1 & 74.85 & 3.17 & \multirow{3}{*}{3.22} \\
\hline & $\mathrm{N} 2$ & 71.60 & 3.04 & \\
\hline & N3 & 81.43 & 3.45 & \\
\hline \multirow{3}{*}{$\begin{array}{l}\text { M-20 with } 0.03 \% \\
\text { glass fiber }\end{array}$} & $3 a$ & 73 & 3.09 & \multirow{3}{*}{3.31} \\
\hline & $3 b$ & 81.4 & 3.45 & \\
\hline & $3 c$ & 79.9 & 3.39 & \\
\hline \multirow{3}{*}{$\begin{array}{l}\text { M-20 with } 0.06 \% \\
\text { glass fiber }\end{array}$} & $6 a$ & 94.90 & 4.02 & \multirow{3}{*}{3.63} \\
\hline & $6 \mathrm{~b}$ & 77.9 & 3.3 & \\
\hline & $6 c$ & 84.43 & 3.58 & \\
\hline \multirow{3}{*}{$\begin{array}{l}\text { M-20 with } 0.1 \% \\
\text { glass fiber }\end{array}$} & $1 \mathrm{a}$ & 132.25 & 5.61 & \multirow{3}{*}{4.58} \\
\hline & $1 \mathrm{~b}$ & 112.20 & 4.76 & \\
\hline & $1 \mathrm{c}$ & 80.03 & 3.39 & \\
\hline
\end{tabular}

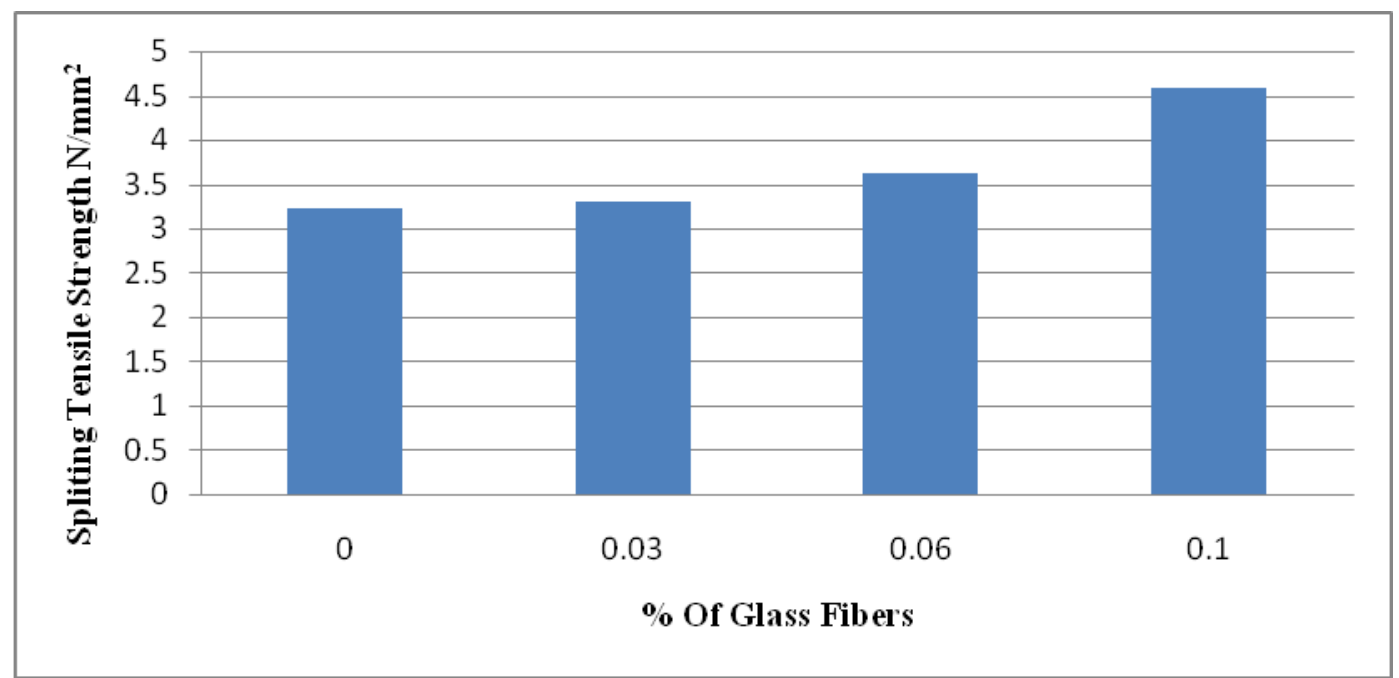

Fig. 3 Splitting Tensile strength of $\%$ of Glass Fiber

\section{Results and Discussions \\ 4.1 Compressive strength}

Table 1 gives the test results of compressive strength at 28 days. Compressive strength increases with increasing percentage of glass fibers. It can be observed that 28 days compressive strength is increased by $8.81 \%$ with addition of $0.03 \%$ of glass fiber compared to normal M-20 concrete. It can be observed that 28 days compressive strength is increased by $11.15 \%$ with addition of $0.06 \%$ of glass fiber compared to normal M-20 concrete. Also it can be observed that 28 days compressive strength is increased by $23.44 \%$ with addition of 0.1 percentage of glass fiber compared to normal M-20 concrete. Concern with percentage of addition of glass fibers are gives better results by addition $0.1 \%$ (Fig. 1).

\subsection{Flexural strength}

Flexural strength increases with increasing percentage of glass fibers. It can be observed that 28 days flexural strength is increased by $7.27 \%$ with addition of $0.03 \%$ of glass fiber compared to normal M-20 concrete (Table 2). It can be observed that 28 days flexural strength is increased by $9.27 \%$ with addition of $0.06 \%$ of glass fiber compared to normal M-20 concrete. Also it can 
IOSR Journal of Engineering

June. 2012, Vol. 2(6) pp: 1308-1312

be observed that 28 days flexural strength is increased by $19.31 \%$ with addition of $0.1 \%$ of glass fiber compared to normal M-20 concrete (Fig. 2).

\subsection{Split tensile strength}

Table 3 gives the test results of splitting tensile strength at 28 days. Flexural strength increases with increasing percentage of glass fibers. It can be observed that 28 days Splitting tensile strength is increased by $2.8 \%$ with addition of $0.03 \%$ of glass fiber compared to normal M-20 concrete. It can be observed that 28 days Splitting tensile strength is increased by $12.73 \%$ with addition of $0.06 \%$ of glass fiber compared to normal M-20 concrete. Also it can be observed that 28 days Splitting tensile strength is increased by $42.23 \%$ with addition of $0.1 \%$ of glass fiber compared to normal M-20 concrete. Concern with percentage of addition of glass fibers are gives better results by addition $0.1 \%$ (Fig. 3).

\section{Conclusions}

The addition of glass fibres into the concrete mixture marginally improves the compressive strength at 28 days. It is observed from the experimental results and its analysis, that the compressive strength of concrete, flexural strength of concrete, splitting tensile strength of concrete increases with addition of Percentage of glass fibers. The $0.1 \%$ addition of glass fibers into the concrete shows better result in mechanical properties and durability.

\section{References}

- Chandramouli K., Srinivasa Rao P., Seshadri Sekhar T., Pannirselvam N. and Sravana P; et al (March 2010) "Rapid Chloride Permeability Test for Durability Studies On Glass Fibre Reinforced Concrete"; VOL. 5, NO. 3, ARPN Journal of Engineering and Applied Sciences pp: $67-71$.

- IS 516 (1999) ,Indian standard methods of tests for strength of concrete, (Reaffirmed 1999), Bureau of Indian Standards , New Delhi.

- IS 456 (2000) Indian standard code of practice for Plain and Reinforced concrete, Bureau of Indian Standards, New Delhi.

- IS 5816 (1970), Method of tests for splitting tensile strength of concrete cylinders, Bureau of Indian Standards, New Delhi.

- IS 8112 Indian standard specification for 43 grade ordinary Portland cement, Bureau of Indian Standards, New Delhi.

- IS 10262 (1982), Recommended guidelines for Concrete Mix Design, Bureau of Indian Standards, New Delhi

- Sheik, S. And Homam M.;(2004) "A Decade of Performance of FRP-Repaired Concrete Structures" Proceedings of the ISIS-SHM 2004 Workshop. Winnipeg, Manitoba, Canada. pp - 751-758.

- Talah Aissa, Kharchi F. and R.Chaid et al., (June2011) "Contribution of natural pozzolana to durability of high performance concrete in chloride environment"; The Indian Concrete Journal pp - $35-45$. 